\title{
THE EFFECT OF CONCEPTION OF INTERNET USAGE AND SMES' ACTIVITIES ON ORGANIZATIONAL PERFORMANCE AMONG TOURISM ENTERPRISES IN MALAYSIA
}

\author{
Fatemeh Sharifonnasabia ${ }^{1}$, Ram Gopal Raj ${ }^{2}$ and Mohd Zuhdi bin Marsukia ${ }^{3}$ \\ ${ }^{1,3}$ Department of Science and Technology Studies, Faculty of Science University of Malaya Lembah Pantai, 50603 \\ Kuala Lumpur, Malaysia
}

${ }^{2}$ Department of Artificial Intelligence, Faculty of Computer Science \& Information Technology, University of Malaya, Lembah Pantai, 50603 Kuala Lumpur, Malaysia

Tel.: 603-79676317

Fax: 603-79579249

Email : fatemehsharifonnasabi24@gmail.com¹,ramdr@um.edu.my²,mzuhdi@um.edu.my³

DOI: https://doi.org/10.22452/mjcs.vol31no3.4

\begin{abstract}
Small and Medium Enterprises (SMEs) are the mainstays of economic development and advancement in numerous countries. SMEs add to monetary advancement in Malaysia by temperance of their utter numbers, expanded share of business and total national output. Innovation reception and Internet utilization development in Malaysian SMEs have enhanced the execution and primary concern of SMEs and information technology (IT) has turned out to be instrumental to the advancement and thriving of different areas. This study assesses the impact of view of Internet utilization, SMEs' action and size on authoritative execution in this industry. Seventy-seven, randomly-identified SME organizations with the tourism business were arbitrarily chosen from Kuala Lumpur and Selangor, Malaysia. The information was gathered by means of a self-administrated poll from tourism organizations in these two zones. The information was dissected in view of the Structural Equation Modeling (SEM) utilizing SMART-Partial Least Squares (PLS). The outcomes uncovered that the observation level of Internet utilization and SME movement surpassed the direct level. The SEM discoveries likewise demonstrated that the acknowledgment of Internet use had a huge, constructive outcome on tourism authoritative execution in Malaysia.
\end{abstract}

\section{Keyword: SME, Tourism, Internet adoption, Malaysia}

\subsection{INTRODUCTION}

It is believed that Small Medium Enterprises (SMEs) are the backbone of advancement, business and financial development. Despite the fact that there is no single definition, SMEs are universally known to have an essential part in characterizing the nations' monetary execution [1]. In any case, SMEs are very mindful to go up against novel innovation [2], conceivably because they battle, with asset, the lack in contrast with extensive firms; henceforth, it might be sensible to acknowledge that it is impractical to sum up systems and asset distribution for grasping data innovation of expansive organizations to SMEs. Other than asset lack, organizations' culture, number of workers and association structure may likewise have an effect on or prompt to low levels of innovation acknowledgment by SMEs. All things being equal, SMEs ought to principally focus on creating Internet landing pages that make organization data available to all. Internet has been perceived as specialized instrument that empowers an association to support and change messages effortlessly to embrace interests of all people and conquer fears. In addition, each business needs an online presence to help its pay through online exercises that are done by means of Internet. SMEs can profit by online exercises to change their business. That is, they can comprehend the noteworthiness of the Internet for their development arrangement [3]. IT has been growingly considered as imperative element in enterprise and business writing, inferable from the Internet innovations' effects on SMEs [4, 5]. It can be credited to the way that Internet advancements are curiosities that empower SMEs' development [6].

The obsolete methods for business for mortar and block organizations are developing quickly, and tested by grasping the Internet, predominantly for online business [7]. The IT and Internet have enhanced overall learning dispersion by associating nations and building up a very much arranged worldwide economy [8]. It is demonstrated that few associations, especially SME organizations, are utilizing Internet progressively because of various focal points and openings given by Internet [9]. Additionally, this ceaseless and rising enthusiasm for Internet can be 
ascribed to the mind-blowing development of Internet clients universally. Creating nations have indicated more noteworthy development rates than the created ones [10]. The worldwide economy is ceaselessly disposed toward higher incorporation, through advances in IT. Thus, contributing in the worldwide and territorial markets offers extreme open doors for small organizations [11,12].

Essentially, Internet empowers better execution in business by both immediate and aberrant cost saving, including, however not constrained to, lower cost of info, bring down cost of work and higher efficiency [13]. It is confirmed that open doors given by Internet to developing markets are much more prominent due to simple access to data and cost proficiency. Many studies have investigated the benefits of Internet for SMEs, identifying with e-commerce. Internet is by all accounts, the most interesting alternative for SMEs when offering market insight. Through Internet, they can offer quick support and client administration; thus, recapitalize on their preference as a SME [14].

Upgrades in SME execution have been accounted for development goals, energy to advance and better exchange activities inferable from capabilities given by online businesses [15]. A portion of the fundamental focal points include quicker business, enhanced managerial process and client benefit, basic requesting process, more noteworthy correspondence with clients, enhanced intra-association correspondence, sharing affirmations around the association and accordingly make upper hand [16]. As a synopsis of observational and survey discoveries, there is hearty proof that there is a missing connection between the expanded SME execution and Internet appropriation. Thus, the point of this examination was to research the impression of tourism organizations in Malaysia towards receiving the Internet innovation and its association with hierarchical execution; hence, these two targets were tended to:

- To ascertain the impression of Internet use in organizational performance of tourism SMEs in Malaysia, and

- To examine the relationship between SME attributes (structure and pay) and organizational execution of tourism SMEs in Malaysia.

\subsection{LITERATURE REVIEW}

The rule for SME organizations to receive Internet is not exempted in the tourism business. Comprehensively, travel and tourism are a perceiving fragment of economy as they extensively add to the internal fiscal change and advancement, and the tourism business is viewed as a standout amongst the most vital SME parts. Imaginative headway and tourism have been going as one for an impressive time span [17-19]. The advancement of the Internet in the late 1990s has drastically changed the methods for business operations and strategic practices in the tourism business.

Tourism as a planetary industry and as the best supplier of work on the planet, it brags a more vital show of heterogeneous accomplices than various distinctive business wanders [20]. In Malaysia, the higher quantities of Internet customers exhibit the high care to IT data. In 2011, the quantity of enrolled Internet customers in Malaysia totaled 17.7 million. The Malaysian SME associations are creating thorough advancement through Internet use, considering the rate of improvements experienced in one year [21]. Malaysia is expected to draw more than 36 million voyagers every year by 2020 [22]. As shown by the Malaysian Tourism Joint effort and Relocation division, the total number of guests in the country in 2012 totaled 25,032,708 from 46 countries, while it was 24,714,324 in 2011 from similar countries. In addition, access to appropriations, practical learning and business segment information are normal bars among the SMEs in the East Asian countries. This is a major development in one year inferable from the ascent of innovation appropriation and Internet use in the Malaysian SME organizations, which have expanded their execution and financial matters. Access to fund, connected science, able HR and market data are normal deterrents among the SMEs in the East Asian nations [23].

In Malaysia, the need to get to fund, the restricted reception of innovation, absence of skilled HR, contenders with multinational inlet windows and globalization are the key snags to market extension for SMEs [24]. Be that as it may, it is not clear regardless of whether this is valid for little and medium-sized tourism organizations. Most studies on the Internet adoption have been led in cutting edge economies [7]. Business exchanges by means of the Internet (internet business and e-business) are still uncommon among the SMEs in Malaysia [25] due to little information and communications technology (ICT) utilization [26]. In Malaysia, a rate of factors that speak to a constraint to market improvement and progression of SMEs joins the nonattendance of powerful subsidizing/credit, lack of getting a handle on development, nonappearance of fit and instructed HR, competition with multinational delta 
windows and globalization [25, 27]. By and by, it is not definitive whether these are correlated to small and medium-sized organizations in tourism industry.

In spite of the fact that there are various investigates on the Internet reception by organizations in the most recent couple of years, there is still a scarcity of this sort of research in some nations like Malaysia [28]. Essentially, most studies on the Internet adoption have been, for the most part, directed in advanced economies and business dealings. E-commerce and e-business are still exceptionally extraordinary among SMEs in Malaysia [29]; mostly commit minute noticeable quality on the utilization of ICT [26]. Regardless, SMEs in Malaysia just contain 14\% of the total SME establishments of the country [21]. This exhibits the level of care and planning to grasp ICT is still low among the Malaysian SMEs. Table 1 indicates Internet reception in Tourism Small and Medium Undertakings in various nations.

Table 1: Internet adoption in Tourism Small and Medium Enterprises in some countries

\begin{tabular}{|c|c|c|c|c|c|}
\hline Ref. & Objective & $\begin{array}{l}\text { Method of } \\
\text { data } \\
\text { collection }\end{array}$ & $\begin{array}{c}\text { Problem } \\
\text { statement }\end{array}$ & Major variables & Major findings \\
\hline$[30]$ & $\begin{array}{l}\text { Explore the } \\
\text { impact of the } \\
\text { Internet on } \\
\text { travel } \\
\text { agencies }\end{array}$ & $\begin{array}{l}\text { Questionnai } \\
\text { re survey }\end{array}$ & $\begin{array}{l}\text { Very limited } \\
\text { studies } \\
\text { investigate both } \\
\text { negative and } \\
\text { positive impact } \\
\text { of the Internet in } \\
\text { the context of } \\
\text { Hong Kong }\end{array}$ & $\begin{array}{l}\text { Internet usage and } \\
\text { effectiveness of the } \\
\text { Internet }\end{array}$ & $\begin{array}{c}\text { Travel agencies have } \\
\text { positive attitudes } \\
\text { towards Internet } \\
\text { applications, potential } \\
\text { threats have not } \\
\text { affected the industry, } \\
\text { and significant } \\
\text { relationships exist } \\
\text { between age, size and } \\
\text { some Internet } \\
\text { attributes }\end{array}$ \\
\hline$[31]$ & $\begin{array}{l}\text { Investigate } \\
\text { factors } \\
\text { behind the } \\
\text { poor Internet } \\
\text { adoption } \\
\text { among travel } \\
\text { agencies in } \\
\text { Malaysia; } \\
\text { identify the } \\
\text { slow pace of } \\
\text { Internet } \\
\text { permeation } \\
\text { into travel } \\
\text { agencies }\end{array}$ & $\begin{array}{l}\text { Online } \\
\text { questionnai } \\
\text { re, print } \\
\text { questionnai } \\
\text { re, and } \\
\text { interview }\end{array}$ & $\begin{array}{c}\text { Slow pace of } \\
\text { Internet adoption } \\
\text { by travel } \\
\text { agencies }\end{array}$ & $\begin{array}{l}\text { Internet usage, } \\
\text { perception towards e- } \\
\text { commerce, and } \\
\text { Internet-based } \\
\text { technology }\end{array}$ & $\begin{array}{l}\text { Malaysian travel } \\
\text { agencies are positive } \\
\text { towards electronic } \\
\text { business. Internet } \\
\text { usage among travel } \\
\text { agencies is in the early } \\
\text { stages, and adopting } \\
\text { the practice of e- } \\
\text { business is low among } \\
\text { agencies }\end{array}$ \\
\hline$[32]$ & $\begin{array}{l}\text { Study the } \\
\text { attitude and } \\
\text { usage of } \\
\text { Internet } \\
\text { technology } \\
\text { among } \\
\text { tourism } \\
\text { agents }\end{array}$ & $\begin{array}{l}\text { Online } \\
\text { questionnai } \\
\text { re survey }\end{array}$ & $\begin{array}{l}\text { Very few studies } \\
\text { investigate the } \\
\text { state of Internet } \\
\text { usage, attitude } \\
\text { towards using the } \\
\text { Internet, } \\
\text { perception of } \\
\text { Internet } \\
\text { marketing and } \\
\text { maturity of web } \\
\text { sites }\end{array}$ & $\begin{array}{l}\text { Internet marketing, } \\
\text { web sites, Internet } \\
\text { applications }\end{array}$ & $\begin{array}{l}\text { Facilitate global } \\
\text { marketing and } \\
\text { improvement of online } \\
\text { services. Relatively } \\
\text { small numbers of } \\
\text { transactions are done } \\
\text { through the Internet. } \\
\text { Web pages are merely } \\
\text { used for disseminating } \\
\text { static information }\end{array}$ \\
\hline$[33]$ & $\begin{array}{l}\text { Investigate } \\
\text { the impact of } \\
\text { e-commerce } \\
\text { usage on the } \\
\text { performance }\end{array}$ & $\begin{array}{l}\text { Questionnai } \\
\text { re survey }\end{array}$ & $\begin{array}{l}\text { Involvement of } \\
\text { tourism industries } \\
\text { in e-commerce in } \\
\text { Malaysia is still } \\
\text { in its formative }\end{array}$ & $\begin{array}{l}\text { Organizational } \\
\text { context, technology } \\
\text { competence and } \\
\text { environmental context }\end{array}$ & $\begin{array}{l}\text { The relationship } \\
\text { between Internet } \\
\text { marketing usage and } \\
\text { business profitability } \\
\text { issignificantly }\end{array}$ \\
\hline
\end{tabular}




\begin{tabular}{|c|c|c|c|c|c|}
\hline & $\begin{array}{c}\text { of businesses } \\
\text { in the tourism } \\
\text { industry }\end{array}$ & & stages & & $\begin{array}{c}\text { moderated by the } \\
\text { number of years of } \\
\text { experience in using } \\
\text { Internet for marketing } \\
\text { purposes }\end{array}$ \\
\hline [34] & $\begin{array}{l}\text { Address the } \\
\text { limitations of } \\
\text { Internet } \\
\text { diffusion } \\
\text { studies }\end{array}$ & $\begin{array}{l}\text { Evaluation } \\
\text { of websites } \\
\text { and emails }\end{array}$ & $\begin{array}{l}\text { Explore the } \\
\text { limitations of } \\
\text { univariate } \\
\text { analysis }\end{array}$ & $\begin{array}{l}\text { Hotel star rating, } \\
\text { affiliation and size, } \\
\text { and internet adoption }\end{array}$ & $\begin{array}{l}\text { There is a positive } \\
\text { relationship between } \\
\text { affiliation and Internet } \\
\text { adoption. Size has } \\
\text { insignificant } \\
\text { relationship with } \\
\text { Internet adoption }\end{array}$ \\
\hline$[35]$ & $\begin{array}{l}\text { Investigate } \\
\text { marketing } \\
\text { information } \\
\text { systems in } \\
\text { tourism } \\
\text { SMEs }\end{array}$ & $\begin{array}{c}\text { Questionnai } \\
\text { re survey }\end{array}$ & $\begin{array}{l}\text { Tourism SMEs in } \\
\text { the Arab region } \\
\text { are reluctant to } \\
\text { adopt Internet } \\
\text { technology }\end{array}$ & Internet usage & $\begin{array}{c}\text { Tourism SMEs utilize } \\
\text { informal marketing } \\
\text { systems that } \\
\text { concentrate on } \\
\text { immediate data at the } \\
\text { expense of external } \\
\text { data }\end{array}$ \\
\hline$[36]$ & $\begin{array}{c}\text { Explore the } \\
\text { major } \\
\text { influential } \\
\text { factors that } \\
\text { determine } \\
\text { Internet usage } \\
\text { for travel and } \\
\text { tourism }\end{array}$ & $\begin{array}{l}\text { Survey data } \\
\text { from the } \\
\text { Institute of } \\
\text { Tourism } \\
\text { Studies, } \\
\text { Spain }\end{array}$ & $\begin{array}{c}\text { Internet } \\
\text { penetration in } \\
\text { Spain is low } \\
\text { compared to } \\
\text { other European } \\
\text { countries }\end{array}$ & Internet usage & $\begin{array}{l}\text { ICT penetration } \\
\text { determines the use of } \\
\text { Internet services }\end{array}$ \\
\hline$[37]$ & $\begin{array}{l}\text { Analyze the } \\
\text { views of } \\
\text { adopters and } \\
\text { non-adopters } \\
\text { of electronic } \\
\text { commerce }\end{array}$ & $\begin{array}{c}\text { Questionnai } \\
\text { re survey }\end{array}$ & $\begin{array}{l}\text { Lack of account } \\
\text { of the factors } \\
\text { influencing the } \\
\text { adoption of e- } \\
\text { commerce by } \\
\text { travel agencies }\end{array}$ & $\begin{array}{l}\text { Government policy, } \\
\text { legal regulation, } \\
\text { centralization, } \\
\text { formalization, } \\
\text { compatibility, relative } \\
\text { advantage, relative } \\
\text { risk, IT security, IT } \\
\text { cost, marketing } \\
\text { competition, supply, } \\
\text { and drive. Vertical } \\
\text { coordination and top } \\
\text { manager's sense }\end{array}$ & $\begin{array}{l}\text { The study indicated } \\
\text { that } 80 \% \text { of the } \\
\text { sampled travel } \\
\text { agencies adopted e- } \\
\text { commerce. Adopters } \\
\text { and non-adopters have } \\
\text { different views on the } \\
\text { compatibility of } \\
\text { adopting technology, } \\
\text { organization } \\
\text { centralization, } \\
\text { organization scale, } \\
\text { and correctness of } \\
\text { website transmission }\end{array}$ \\
\hline$[38]$ & $\begin{array}{l}\text { Understand } \\
\text { and capture } \\
\text { the progress } \\
\text { of innovation } \\
\text { in the tourism } \\
\text { industry }\end{array}$ & $\begin{array}{l}\text { Collected } \\
\text { data from } \\
\text { tourism } \\
\text { awards } \\
\text { database }\end{array}$ & $\begin{array}{l}\text { Tourism sector } \\
\text { system } \\
\text { innovation and } \\
\text { production are } \\
\text { changing in a } \\
\text { complex form, } \\
\text { which makes } \\
\text { evaluating } \\
\text { innovative events } \\
\text { problematic } \\
\end{array}$ & $\begin{array}{l}\text { Knowledge bases and } \\
\text { technologies, actors } \\
\text { and networks, and } \\
\text { innovative intensity }\end{array}$ & $\begin{array}{l}\text { Internal and external } \\
\text { factors have an impact } \\
\text { on the adoption of e- } \\
\text { marketing among } \\
\text { small Egyptian } \\
\text { tourism organizations }\end{array}$ \\
\hline [39] & $\begin{array}{l}\text { Analyzed } \\
\text { factors } \\
\text { affecting the } \\
\text { adoption of } \\
\text { electronic }\end{array}$ & $\begin{array}{c}\text { Questionnai } \\
\text { re survey }\end{array}$ & $\begin{array}{l}\text { Need to } \\
\text { understand the } \\
\text { factors that } \\
\text { influence e- }\end{array}$ & $\begin{array}{l}\text { Owner skills and } \\
\text { support; organizational } \\
\text { culture, resources and } \\
\text { size; cost, ease of use, } \\
\text { relative advantage, and }\end{array}$ & $\begin{array}{c}\text { Technology } \\
\text { competence, firm size, } \\
\text { firm scope, web } \\
\text { technology } \\
\text { investment, pressure }\end{array}$ \\
\hline
\end{tabular}




\begin{tabular}{|c|c|c|c|c|c|}
\hline & $\begin{array}{c}\text { marketing } \\
\text { among } \\
\text { tourism } \\
\text { organizations }\end{array}$ & & $\begin{array}{l}\text { marketing } \\
\text { adoption }\end{array}$ & compatibility & $\begin{array}{l}\text { intensity, and back- } \\
\text { end usage have } \\
\text { significant influence } \\
\text { on e-commerce usage }\end{array}$ \\
\hline$[40]$ & $\begin{array}{l}\text { Investigate } \\
\text { the view of } \\
\text { web } \\
\text { marketing } \\
\text { business } \\
\text { adopters and } \\
\text { non-adopters } \\
\text { among } \\
\text { tourism } \\
\text { agencies }\end{array}$ & $\begin{array}{l}\text { Questionnai } \\
\text { re survey, } \\
\text { Roger's } \\
\text { diffusion of } \\
\text { innovation } \\
\text { theory }\end{array}$ & $\begin{array}{l}\text { Measure web } \\
\text { adoption as } \\
\text { continuum not } \\
\text { dichotomous }\end{array}$ & $\begin{array}{l}\text { Relative advantage, } \\
\text { compatibility, } \\
\text { perceived risk, } \\
\text { marketing capability, } \\
\text { employee IT } \\
\text { knowledge, } \\
\text { organization learning, } \\
\text { marketing orientation, } \\
\text { top management } \\
\text { support, attitude } \\
\text { towards change, and } \\
\text { response to risk }\end{array}$ & $\begin{array}{l}\text { Innovation attributes } \\
\text { are not drivers in the } \\
\text { study of firm adoption } \\
\text { of web marketing, but } \\
\text { the resources of a firm } \\
\text { affect decisions to } \\
\text { adopt web marketing. } \\
\text { Adoption depends on } \\
\text { different factors }\end{array}$ \\
\hline$[41]$ & $\begin{array}{l}\text { Investigates } \\
\text { Internet } \\
\text { adoption in } \\
\text { TAs across } \\
\text { the United } \\
\text { Arab } \\
\text { Emirates } \\
\text { (UAE) }\end{array}$ & $\begin{array}{l}\text { Research is } \\
\text { based on a } \\
\text { questionnai } \\
\text { res survey }\end{array}$ & $\begin{array}{l}\text { Internet usage is } \\
\text { at an advanced } \\
\text { stage among TAs } \\
\text { in the UAE }\end{array}$ & $\begin{array}{l}\text { Internet adoption in } \\
\text { travel agents across the } \\
\text { United Arab Emirates }\end{array}$ & $\begin{array}{l}\text { Finding is that TAs in } \\
\text { the UAE appear to be } \\
\text { at least aware of the } \\
\text { necessity to adopt } \\
\text { Internet to a certain } \\
\text { extent }\end{array}$ \\
\hline$[42]$ & $\begin{array}{c}\text { To } \\
\text { investigate } \\
\text { the perceived } \\
\text { barriers to e- } \\
\text { commerce } \\
\text { adoption in } \\
\text { Egyptian } \\
\text { travel agents }\end{array}$ & $\begin{array}{l}\text { This study, } \\
\text { using } \\
\text { structural } \\
\text { equation } \\
\text { modelling } \\
\text { with a } \\
\text { sample of } \\
411 \text { travel } \\
\text { agents }\end{array}$ & $\begin{array}{l}\text { Perceived } \\
\text { barriers to } \\
\text { E- } \\
\text { commerce } \\
\text { adoption In } \\
\text { SMEs in } \\
\text { developing } \\
\text { countries }\end{array}$ & 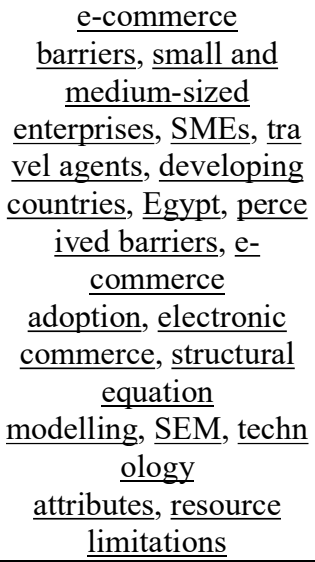 & $\begin{array}{l}\text { The research findings } \\
\text { reveal that technology } \\
\text { attributes and resource } \\
\text { limitations are the } \\
\text { most perceived } \\
\text { barriers from } \\
\text { managers' viewpoint }\end{array}$ \\
\hline
\end{tabular}

Along these lines, most of the previous literature reviews (Table 1) on central point affecting the Internet adoption in the tourism segment utilized rates, which restrict the investigation of criticalness contrasts among the compelling variables. From the perspective of the tourism, exceptionally restricted studies have investigated the contrasts amongst negative and positive discernments with respect to the effect of Internet reception, particularly with regards to Malaysia. With the potential for fast development in the Malaysia's tourism area, so far extremely constrained writing has researched the speculation benefits prior and then afterward Internet appropriation from the point of view of tourism organizations. This hole is additionally noted with regards to Malaysian tourism organizations. With the possibility of remarkable development in the tourism segment of Malaysia, there is a need to explore arrangements of extending Internet offices to adapt to this foreseen development.

\subsection{RESEARCH METHODOLOGY}

In this survey study, a questionnaire form was utilized as the information accumulation tool to produce a diagram of Internet use in the travel agents around Malaysia. The outline of the organized survey took after the past writing. Information was gathered from the SMEs crosswise over Malaysian tourism businesses that were effectively embracing Internet. The free factors were the impression of Internet adoption and the SMEs' circumstance and 
exercises, while the needy variable was the hierarchical execution advancement. Selections of Internet have gotten impressive enthusiasm from industry bunches arrangement creators, and researchers. Broad examination of the hypothetical system of the study uncovered the benefits of the accompanying hypothetical models to look at the level of internet adoption: the Theory of Planned Behavior (TPB) [43] and the Technology Acceptance Model (TAM) [44].

\subsection{Theory of Planned Behavior (PBC)}

The hypothesis of Planned Behavior [43] is an expansion for the hypothesis of Theory of Reasoned Action (TRA) and was built up for overcoming on TRA confinement. Hypothesis of Planned Behavior involves demeanor, subjective standard and Perceived Behavioral Control (PBC) (Ajzen, 1985, 1991). Hypothesis of arranged conduct model is shown in Fig. 1. As per the hypothesis, state of mind towards conduct, subjective standards, and perceived behavioral control, together affect behavior.

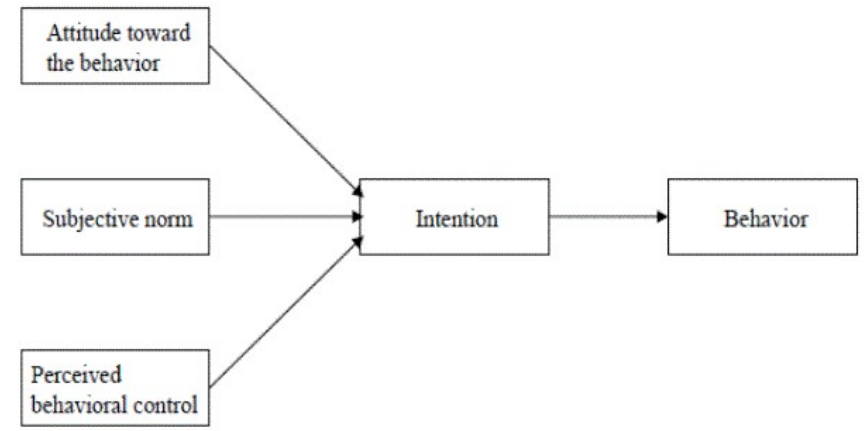

Fig. 1: Theory of planned behavior (Ajzen, 1991)

\subsection{Technology Acceptance Model (TAM)}

This model is a data frameworks hypothesis that displays how clients acknowledge and utilize an innovation as shown in Fig. 2. The model recommends that when clients are given another innovation, various variables affect their choice about how and when they will utilize the innovation. TAM is a model of client acknowledgment of data frameworks innovation in view of the hypothesis of contemplated activity, and since this examination concentrated on Internet use among SMEs; therefore, a part of the last structure outlined by model.

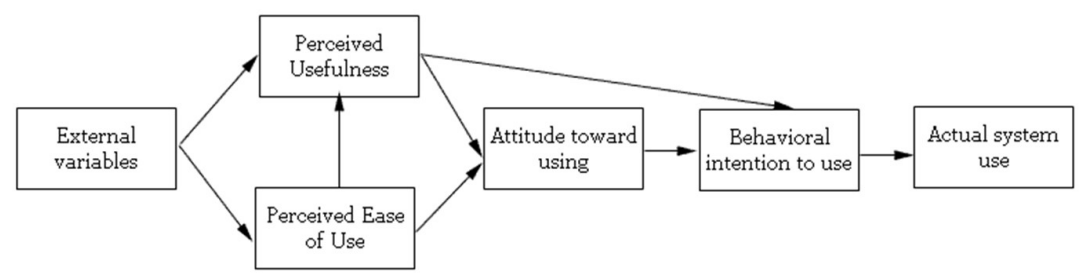

Fig. 2: Technology acceptance model (TAM), Davis (1986)

The institutional hypothesis has likewise been utilized broadly in firm-level studies. A few studies clarified that no single unitary hypothesis can clarify all parts of development acknowledgment $[45,46]$. Thus, most research is on the appropriation of adoption of Internet on single or consolidated utilization of the selection models. The incorporated model created in this study was then observationally assessed inside the Malaysian Tourism Industry through a quantitative study ponder. A portion of the utilized hypothetical elements to assess the impacts of Internet adoption is sketched out in Table 2 . 
Table 2: Some of the theoretical factors used to examine the impact level of Internet adoption

\begin{tabular}{|c|c|c|}
\hline Research constructs & Definition & Source \\
\hline Perceived Usefulness & $\begin{array}{c}\text { The extent to which a supervisor accepts that utilizing web would } \\
\text { upgrade his or her occupation execution }\end{array}$ & {$[44]$} \\
\hline Perceived Ease of Use & $\begin{array}{c}\text { The extent to which a supervisor accepts that utilizing the web would be } \\
\text { free of exertion }\end{array}$ & {$[44]$} \\
\hline Subjective Norm & $\begin{array}{c}\text { Speaks to the extent to which a chief sees that essential others accept he } \\
\text { or she ought to utilize the web }\end{array}$ & {$[47]$} \\
\hline Attitude & Decision maker's positive or negative feelings about internet adoption & {$[44]$} \\
\hline Intention & Decision maker's readiness to adopt the internet & {$[44]$} \\
\hline Image & $\begin{array}{c}\text { The extent to which internet adoption is perceived to enhance one's } \\
\text { image or status in one's social system }\end{array}$ & {$[48]$} \\
\hline Facilitating conditions & $\begin{array}{c}\text { The extent to which a leader accepts that the assets obliged exists to } \\
\text { bolster utilization of the web }\end{array}$ & {$[49]$} \\
\hline Perceived risk & $\begin{array}{c}\text { Instability that the leaders face when they can't anticipate the outcomes } \\
\text { of their choice }\end{array}$ & {$[50]$} \\
\hline
\end{tabular}

The study trial was chosen based on the variability and homogeneity in the whole populace and included all the SMEs $(n=77)$ situated in Selangor and Kuala Lumpur territories. Random technique was utilized for the examination. The proposed think about structure is introduced in Fig. 3. There are three phases in this propose structure which include two independent variables and one dependent variable. The first independent variable is impression of internet usage that includes eight sub measurements which are utilized for measurement of the effect level of Internet appropriation, (Perceived Usefulness, Perceived Ease of Use, Subjective Norm, Attitude, Intention, Image, Facilitating conditions, Perceived Risk). The second independent variable is SMEs attributes (Income, Size, and Business Structure). Each one of these parts has impact on measuring the aftereffect of ward segment which is hierarchical execution.

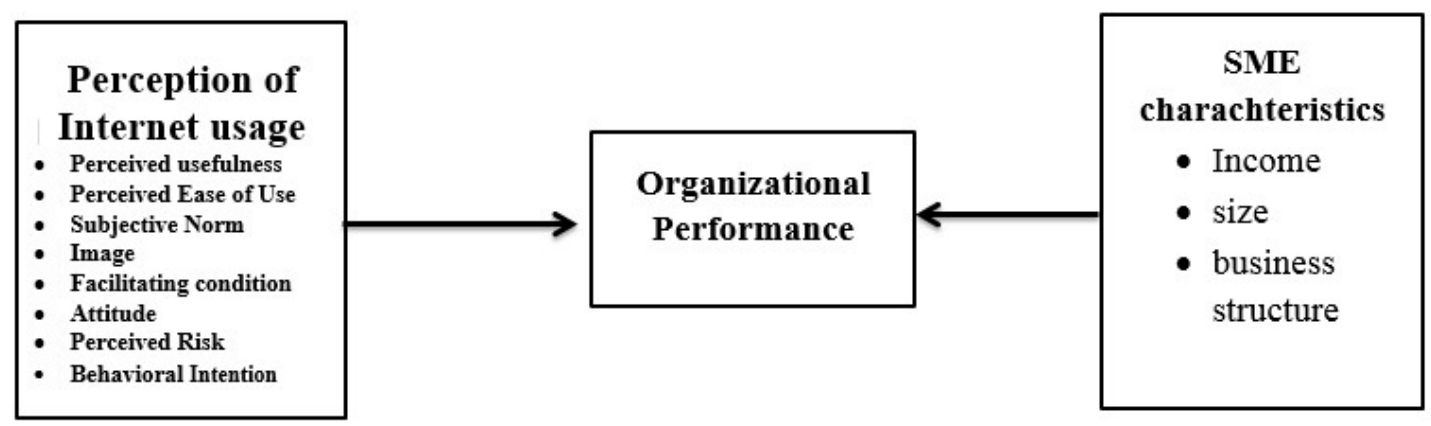

Fig. 3: The Proposed Framework of this study based on TAM \& PBC

\subsection{Instruments}

The questionnaire of this study comprised of three sections: section one, which requested that the respondents answer eight general scale questions created by Narver and Slater (1990); section two, which looked to catch the impression of respondents towards Internet appropriation by 16 inquiries from the TAM [44] and TPB [43]; section three, which included data about the real Internet use in SMEs. Every one of the inquiries in the initial three sections of the poll were surveyed utilizing a five-point Likert scale with end focuses portrayed by 'firmly deviate' $=1$ and 'Unequivocally concur' $=5$. In conclusion, an extra part was a pilot testing directed at the poll's perception and taking out potential issues, keeping in mind the end goal of the survey. The survey content legitimacy was confirmed by specialists in the exploration zone. Cronbach's alpha coefficient was utilized to test the dependability 
of the poll scales [51]. Thus, a few inquiries were enhanced and a couple of proclamations were made more appropriate to the Malaysian circumstance.

The pilot testing of the instrument was led on 16 tourism organizations to quantify the instrument reliability. The reliability coefficients for various areas of the survey were computed in the pilot study. Accordingly, in light of the reliability alpha, those factors with qualities more noteworthy than the standard of 0.70 were viewed as solid. Cronbach's Alpha Estimation of the Instruments of the pilot test is shown in Table 3.

Table 3: Cronbach's Alpha Value of the Instruments

\begin{tabular}{|l|l|l|}
\hline Dimension & $\begin{array}{l}\text { Number of } \\
\text { Items (n=30) }\end{array}$ & $\begin{array}{l}\text { Cronbach's Alpha } \\
\text { (Pilot study) }\end{array}$ \\
\hline Perceived Usefulness & 6 & 0.88 \\
\hline Perceived Ease of Use & 5 & 0.89 \\
\hline Subjective Norm & 2 & 0.68 \\
\hline Image & 3 & 0.81 \\
\hline Facilitating Condition & 3 & 0.88 \\
\hline Attitude & 4 & 0.86 \\
\hline Perceived Risk & 3 & 0.88 \\
\hline Behavioral Intention & 3 & 0.92 \\
\hline Organizational Performance & 7 & 0.83 \\
\hline Perception & 10 & 0.78 \\
\hline Internet Usage & 16 & 0.9 \\
\hline Total & 62 & 0.72 \\
\hline
\end{tabular}

\subsection{Data Collection and sampling}

The information is gathered from tourism organizations in Malaysia. As per [52], 197 tourism SMEs organizations are enlisted in Malaysia and they are for the most part situated in Kuala Lumpur (73 tourism organizations) and Selangor (64 tourism organizations), making a sum of 137 tourism organizations contrasted with different regions (8 in Terengganu, and 7 in Sabah). Along these lines, Kuala Lumpur and Selangor are chosen as our study zones and 100 questionnaires were sent for review through stratified random testing. An aggregate of 82 questionnaires were returned where 77 were usable for data analysis purpose.

To guarantee that there is no Normal Strategy Predisposition in the questionnaires, we played out Cronbach's Alpha test. These organizations are enlisted with the SME Enterprise Malaysia, which is a foundation for the advancement and direction of the Malaysian SMEs. The organization database does not give sites and email locations of the enlisted tourism organizations; consequently, we hunt down the individual sites and messages in Google and Yahoo by entering in their names. The objective members were staff with senior positions in the association, for example, CEO, supervisors, managing directors, executive and head of IT, since they were required to have wide information on the organization's operations by experience. The surveys were circulated as printed copy and online for three months in April 2014.

For the statistical data analysis, the gathered information was coded into SPSS 21. Graphic insights, including recurrence, mean and standard deviation were utilized to investigate the level and conveyance of research factors. Confirmatory Factor Analysis [53] (CFA) was utilized to assess the legitimacy (concurrent and discriminant [54]) of the poll. To answer the examination questions, Structural Equation Modeling (SEM) was connected utilizing SmartPLS [55]. 


\subsection{RESULTS AND DISCUSSION}

The contributors in this study were from various backgrounds. The respondents' attributes are exhibited in Table 4. The outcomes demonstrate that $51.9 \%$ of the respondents were males and $48.1 \%$ were females. In light of frequency analysis, Malay race had the most astounding recurrence with 39\%, trailed by Chinese (35.1\%). Concerning the respondents' educational level, the most elevated recurrence $(66.2 \%)$ had a place with the Diploma holders, trailed by degree $(24.7 \%)$. These outcomes additionally uncovered that $67.5 \%$ of the respondents utilized IT as a part of their employment or organization.

Table 4: Frequency distribution of respondents' background and characteristic

\begin{tabular}{|l|l|l|l|}
\hline Variable & \multicolumn{2}{l}{ n } \\
\hline \multirow{4}{*}{ Gender } & Male & 40 & 51.9 \\
\cline { 2 - 4 } & Female & 37 & 48.1 \\
\hline \multirow{5}{*}{ Race } & Malay & 30 & 39 \\
\cline { 2 - 4 } & Chinese & 27 & 35.1 \\
\cline { 2 - 4 } & Indian & 8 & 10.3 \\
\cline { 2 - 4 } & Other & 12 & 15.6 \\
\hline \multirow{5}{*}{ Education } & Diploma & 51 & 66.2 \\
\cline { 2 - 4 } & Bachelor BS/BA & 19 & 24.7 \\
\cline { 2 - 4 } & Master/MBA/MS & 4 & 5.2 \\
\cline { 2 - 4 } & Doctorate & 2 & 2.6 \\
\cline { 2 - 4 } & Others & 1 & 1.3 \\
\hline \multirow{2}{*}{ Using IT } & Yes & 52 & 67.5 \\
\cline { 2 - 4 } & No & 25 & 32.5 \\
\hline
\end{tabular}

\subsection{SME Characteristics}

A few inquiries were intended to assess the qualities of SEMs, for example, accessibility, wage, number of staff, sorts of activities and sorts of tours managed by these organizations. As per the outcomes, in 2014, 35.1\% of the organizations were found near a train station, while $33.8 \%$ were almost near to parking lots. Assessing the level of wage demonstrated that most organizations had salary of more than RM 50,000 (41.6\%), trailed by organizations with wage between RM 10,000 and 20,000 (35.1\%). Most SMEs were in business for less than five years (29.9\%) and just $27.3 \%$ were dynamic for over 15 years. Just 30 organizations (39\%) had no less than one branch and $61 \%$ had no branches in different spots. The most essential activities among these SMEs were tours $(72.7 \%)$, trailed by transportation (20.8\%). Assessing the kind of tours among the SMEs demonstrated that cultural (53.2\%) and Edutourism $(15.6 \%)$ had the most astounding frequencies (Table 5). 
Table 5: Frequency distribution of the SME characteristics

\begin{tabular}{|c|c|c|c|}
\hline \multicolumn{2}{|l|}{ Characteristics } & \multirow{2}{*}{$\begin{array}{ll}\% \\
35.1\end{array}$} & \multirow{2}{*}{$\begin{array}{l}\mathbf{n} \\
27\end{array}$} \\
\hline My Company near to & Metro & & \\
\hline & Highway & 9.1 & 7 \\
\hline & Buss-Station & 6.5 & 5 \\
\hline & Taxi-Station & 13 & 10 \\
\hline & Parking Space & 33.8 & 26 \\
\hline \multirow[t]{3}{*}{ Company income } & $>$ RM 10000 & 23.4 & 18 \\
\hline & RM 10001-20000 & 35.1 & 27 \\
\hline & $<$ RM 50000 & 41.6 & 32 \\
\hline \multirow[t]{4}{*}{ Age of business } & Less than 5 years & 29.9 & 23 \\
\hline & 6 to 10 years & 23.4 & 18 \\
\hline & 11 to 15 years & 19.5 & 15 \\
\hline & more than 15 years & 27.3 & 21 \\
\hline \multirow{2}{*}{$\begin{array}{l}\text { Do you have any other branch of your } \\
\text { company? }\end{array}$} & Yes & 39 & 30 \\
\hline & No & 61 & 47 \\
\hline \multirow[t]{4}{*}{ Activities } & Resturant and food & 2.6 & 2 \\
\hline & Tour and tourism & 72.7 & 56 \\
\hline & Accomodation & 3.9 & 3 \\
\hline & Transport & 20.8 & 16 \\
\hline \multirow[t]{6}{*}{ Types of tourism } & Medical tourism & 6.5 & 5 \\
\hline & Edu-tourism & 15.6 & 12 \\
\hline & Sport tourism & 6.5 & 5 \\
\hline & Ecotourism & 13 & 10 \\
\hline & Cultural tourism & 53.2 & 41 \\
\hline & Adventure tourism & 5.2 & 4 \\
\hline \multirow{2}{*}{\multicolumn{2}{|c|}{ Number of employees }} & Mean & SD \\
\hline & & 12.4 & 15.02 \\
\hline
\end{tabular}

\subsection{Measurement Model}

The measurement model is vital as it tests the reliability of the observed variables employed to gauge the idle factors. An estimation model that offers a poor fit to the information recommends that at any rate, a portion of the indicator variables are untrustworthy, and prevents the researcher from dissecting the structural model.

Tables 6 displays the measurement model from the yield of SmartPLS. The values acquired from the outer loading show the variable stacking for every pointer. Individual thing's unwavering quality can be surveyed by assessing the individual item loading with qualities more prominent than 0.7 , which demonstrates adequate reliability or correlation for each construct $[56,57]$. However, $[58,59]$ further recommended the acceptable factor loading (outer loading) to be 0.4 for the example size of at least 200 . The new created sizes of 0.50 or higher ought to be held in the estimation show. Consequently, the external loading beneath 0.50 ought to be expelled from the estimation models as a result of less commitment towards these elements. The aftereffects of corroborative component examination additionally showed that every one of the things identified with the view of Internet utilization essentially added to the related sub measurement with a stacking element estimation of higher than 0.5 for every one of the things (Table 6). Composite Reliability [60] (CR) bigger than 0.7 is adequate; in this manner, the CR taking after the change of unwavering quality of the survey was conceivable by means of evacuating the announcements that expanded 
blunder. In this study, the CR was from 0.883 to 0.961 . Likewise, the AVE (Average Variance) was over 0.5 (Table 6). The AVE for every development was more than each of the squared connection between the construct. Along these lines, the outcomes demonstrate that AVE and CR were worthy for development of this study.

Table 6: Convergent validity results and Outer Loading for based on Measurement model

\begin{tabular}{|c|c|c|c|c|c|}
\hline variable & Item & Outer Loading & AVE & $\begin{array}{l}\text { Composite } \\
\text { Reliability }\end{array}$ & $\begin{array}{c}\text { Cronbach's } \\
\text { Alpha }\end{array}$ \\
\hline \multirow{4}{*}{ Attitude } & ATT1 & 0.75 & 0.725 & 0.913 & 0.871 \\
\hline & ATT2 & 0.93 & & & \\
\hline & ATT3 & 0.93 & & & \\
\hline & ATT4 & 0.84 & & & \\
\hline \multirow{3}{*}{$\begin{array}{l}\text { Behavioral } \\
\text { Intention }\end{array}$} & BEH.IN1 & 0.95 & 0.891 & 0.961 & 0.939 \\
\hline & BEH.IN2 & 0.93 & & & \\
\hline & BEH.IN3 & 0.95 & & & \\
\hline \multirow{3}{*}{$\begin{array}{l}\text { Facilitating } \\
\text { condition }\end{array}$} & FACIL1 & 0.87 & 0.856 & 0.947 & 0.916 \\
\hline & FACIL2 & 0.95 & & & \\
\hline & FACIL3 & 0.93 & & & \\
\hline \multirow[t]{3}{*}{ Image } & IMG1 & 0.90 & 0.715 & 0.883 & 0.801 \\
\hline & IMG2 & 0.89 & & & \\
\hline & IMG3 & 0.83 & & & \\
\hline \multirow{5}{*}{$\begin{array}{l}\text { Perceived Ease } \\
\text { of Use }\end{array}$} & P.E.USE1 & 0.89 & 0.724 & 0.929 & 0.904 \\
\hline & P.E.USE2 & 0.90 & & & \\
\hline & P.E.USE3 & 0.92 & & & \\
\hline & P.E.USE4 & 0.94 & & & \\
\hline & P.E.USE5 & 0.83 & & & \\
\hline \multirow{3}{*}{ Perceived Risk } & P.RISK1 & 0.92 & 0.875 & 0.954 & 0.929 \\
\hline & P.RISK2 & 0.95 & & & \\
\hline & P.RISK3 & 0.93 & & & \\
\hline \multirow{6}{*}{$\begin{array}{l}\text { Perceived } \\
\text { Usefulness }\end{array}$} & P.USE1 & 0.90 & 0.756 & 0.949 & 0.935 \\
\hline & P.USE2 & 0.92 & & & \\
\hline & P.USE3 & 0.81 & & & \\
\hline & P.USE4 & 0.82 & & & \\
\hline & P.USE5 & 0.88 & & & \\
\hline & P.USE6 & 0.85 & & & \\
\hline \multirow{2}{*}{$\begin{array}{l}\text { Subjective } \\
\text { Norm }\end{array}$} & SN1 & 0.96 & 0.901 & 0.948 & 0.890 \\
\hline & SN2 & 0.97 & & & \\
\hline \multirow{9}{*}{$\begin{array}{l}\text { Organizational } \\
\text { Performance }\end{array}$} & PERF1 & 0.75 & 0.660 & 0.930 & 0.910 \\
\hline & PERF2 & 0.89 & & & \\
\hline & PERF3 & 0.86 & & & \\
\hline & PERF4 & 0.85 & & & \\
\hline & PERF5 & 0.84 & & & \\
\hline & PERF6 & 0.87 & & & \\
\hline & PERF7 & 0.58 & & & \\
\hline & PERF1 & 0.75 & & & \\
\hline & PERF2 & 0.89 & & & \\
\hline
\end{tabular}

1=Attitude, 2=Behavioral Intention, 3=Facilitating condition, 4=Image, $5=$ Perceived usefulness, $6=$ Perceived Ease of Use.7=Perceived Risk, $8=$ Subjective Norm, $\mathrm{PERF}=$ Organizational Performance

Discriminant validity can be tested by the AVE for each construct against the squared correlations (shared variance) between one construct and all other constructs in the model. A construct will have adequate discriminant validity if its AVE exceeds the squared correlation among the constructs [61, 62]. Based on Table 7, the AVE for each 
construct was more than each of the squared correlation between the constructs; therefore, the discriminant validity was adequate for all of the constructs.

Table 7: The Results of Discriminant Validity

\begin{tabular}{|l|c|c|c|c|c|c|c|c|c|}
\hline & $\mathbf{1}$ & $\mathbf{2}$ & $\mathbf{3}$ & $\mathbf{4}$ & $\mathbf{5}$ & $\mathbf{6}$ & $\mathbf{7}$ & $\mathbf{8}$ & $\mathbf{9}$ \\
\hline 1. Attitude & $\mathbf{0 . 8 5 2}$ & & & & & & & & \\
\hline 2. Behavioral Intention & 0.802 & $\mathbf{0 . 9 4 4}$ & & & & & & & \\
\hline 3. Facilitating condition & 0.800 & 0.657 & $\mathbf{0 . 9 2 5}$ & & & & & & \\
\hline 4. Image & 0.827 & 0.794 & 0.761 & $\mathbf{0 . 8 4 5}$ & & & & & \\
\hline 5. Perceived usefulness & 0.794 & 0.678 & 0.671 & 0.719 & $\mathbf{0 . 8 7 0}$ & & & & \\
\hline 6. Organizational Performance & 0.520 & 0.437 & 0.453 & 0.493 & 0.592 & $\mathbf{0 . 8 1 2}$ & & & \\
\hline 7. Perceived Ease of Use & 0.762 & 0.658 & 0.631 & 0.745 & 0.878 & 0.619 & $\mathbf{0 . 8 5 1}$ & & \\
\hline 8. Perceived Risk & 0.505 & 0.462 & 0.591 & 0.505 & 0.417 & 0.329 & 0.459 & $\mathbf{0 . 9 3 5}$ & \\
\hline 9. Subjective Norm & 0.576 & 0.478 & 0.449 & 0.662 & 0.619 & 0.497 & 0.699 & 0.320 & $\mathbf{0 . 9 4 9}$ \\
\hline
\end{tabular}

\subsection{Path Analysis}

SMART-Partial Least Squares (PLS) was applied to answer the research questions and evaluate the effect of all the independent variables, including the perception of Internet usage, and SMEs' activities on organizational performance.

In the path analysis, the research questions were addressed:

- Does perception of Internet usage have significant effect on organizational performance of tourism SMEs in Malaysia?

- Do SME characteristics (structure and income) have significant effects on organizational performance on tourism SMEs in Malaysia?

Fig. 4 shows the path model between two constructs (independent variables) including perception of Internet usage (including attitude, behavioral intention, facilitating condition, image, perceived usefulness, perceived ease of use, perceived risk and subjective norm) and SME activities (including number of employee, age of business and income) and organizational performance as dependent variable. The path model includes the outer loading values for inner model (the effect of indicator on each latent variable) which was explained in measurement model section and regression coefficients (effect of perception of Internet usage and SME activities on organizational performance). The results of bootstrapping method in Table 8 showed that all indicators had a significant contribution on latent variables.

To answer the research question, two structural relationships were investigated using bootstrapping method. In this model, both IVs showed a significant and positive relationship with DV, meaning that companies with higher levels of perception of Internet usage as well as higher activity will achieve higher levels of organizational performance.

The effect of perception of Internet usage on organizational performance $(B=0.494, P<0.05)$ was significant and positive. The SME activity also had a significant, positive effect on the organizational performance $(\mathrm{B}=0.293, \mathrm{P}<$ $0.05)$ but it was less than perception of Internet usage.

Table 8: Test of the total effects of independent variables on dependent variable using bootstrapping

\begin{tabular}{|l|c|c|c|c|c|}
\hline Path & $\boldsymbol{\beta}$ & SD & SE & T-statistics & P value \\
\hline Perception -> Performance & 0.494 & 0.055 & 0.055 & 8.964 & $<0.001$ \\
\hline SME -> Performance & 0.293 & 0.042 & 0.042 & 7.017 & $<0.001$ \\
\hline
\end{tabular}




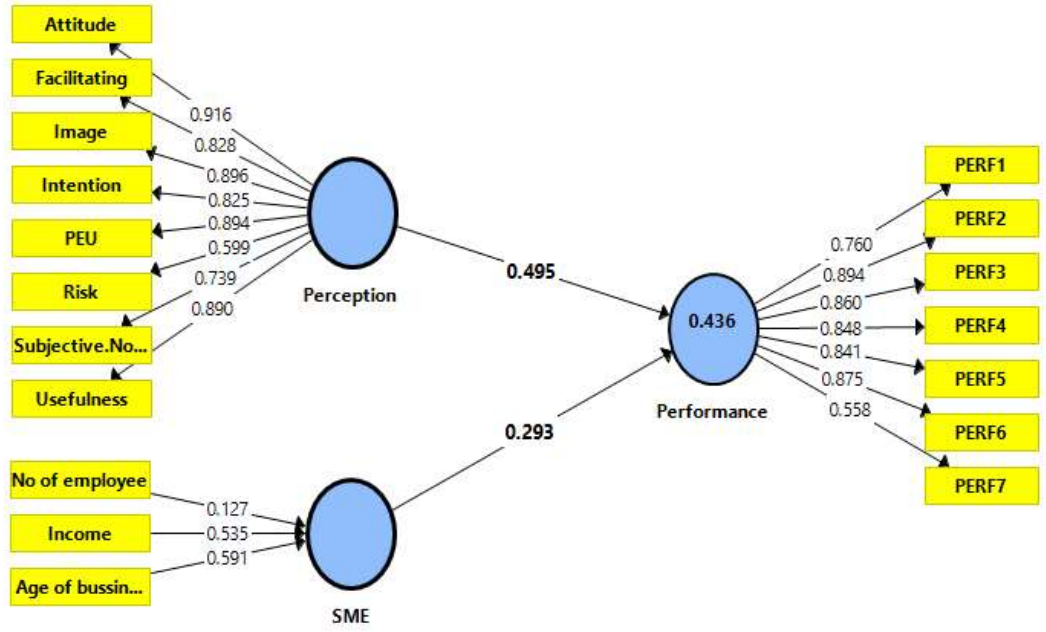

Fig. 4: Path model of factors with effect on organizational performance

The first essential criterion for judging the path model is determination coefficient (R2). The R2 value of the dependent construct measures the total variance explained in DV through independent variables [63]. The R2 coefficient for this model was 0.436 , which indicated that the both perception of Internet usage and SME activity were able to explain 43.6 of the variability in the SMEs' organizational performance. Contrary to other confirmative SEM models, explorative PLS models do not have such indicators to assess the overall model's goodness of fit. The criterion of global fitness ( GoF) was calculated. The GoF is a geometric average of all communalities and R2 in the model. The GoF is an index that can be used to validate models with PLS.

$$
\mathrm{GoF}=\sqrt{ }\left((\text { Communality })^{*} \mathrm{R}^{\wedge} 2\right)=0.522
$$

A GoF value higher than 0.5 shows that the set of structural equations is well-defined and valid, and offering a good representation of the dataset. GoF of the current model was 0.522 , which corresponds to $52 \%$ of the reachable fitness.

\subsection{Limitations}

Certain constraints of this review ought to be recognized. In any case, the case assurance may limit the ability to sum up the discoveries to the general population. Next, notwithstanding the way that the choices for each request were made in light of the past reviews, not all the possible choices may have been joined. Additionally, exhibiting the once-over of potential responses to the respondents may have brought about inclinations in their responses. Additionally, self-reports were used to evaluate Internet apportionment, which may have brought about selfdelivered authenticity and extended causal linkages (Todd and Taylor, 1995). Fluctuation in real use (around 40.5\%) insinuates that the model may have disregarded a few variables. Finally, variance in authentic use (around $40.5 \%$ ) prescribes that the model may have disregarded a couple of segments.

\subsection{Future Research}

In this area, a couple of suggestions for future examination are passed on. Future research could develop this review through across replication over unmistakable cases and over an extent of assorted IT advancements. The acknowledged investigation framework proposed in this review can then serve as commence for hypothesis definition for future research. The review on Internet reception of Malaysian SMEs can be extended to various associations. A longitudinal review would give more undeniable confirmation to the method, through which feelings, attitudes, benchmarks and desires are formed. Prompt investigation on the TAM ought to address the part 
of various determinants of reception/utilization conduct. It is proposed to use more elucidate models, joining additional antecedent that considers past points and behavioral control.

\subsection{CONCLUSION}

This study investigated the Internet attribution by the tourism SMEs in Malaysia (Kuala Lumpur and Selangor), with concentrate on the Internet adoption and utilization, observations on the essentials of Internet on business execution, the statistic characteristics of individuals in the tourism business and the levels of ICT utilization. The exploration was done utilizing a hypothetical structure in light of the past writing. Every one of the ways was tried for the importance, utilizing the bootstrap re-inspecting. The consequences of the structural path investigation of the exploration display bolster the examination questions. Accordingly, this intercession examination, utilizing PLS, means the intervening part of Internet utilization and selection in the connection between the impressions of Internet use, SME exercises and wage. The ICT discernment among the tourism SMEs in Malaysia can be upgraded by the immensely great position of the Internet in the execution and improvement of organizations and simultaneously, the progression of the Malaysia tourism industry. The accompanying conclusions can be drawn:

- The majority of SMEs have not advanced to a state, where the perception of Internet use is regarded as important.

- Web utilization and adoption among the tourism SMEs in Malaysia is higher than moderate.

- Internet perception, SME activities and size of the SME have significant, positive effects on Internet usage and adoption.

- Internet perception and SME activities can significantly improve the organizational performance of the SMEs.

The motivation behind this study was to build up an Internet adoption decision model for the Malaysian Tourism SMEs with the assistance of fundamental behavioral speculations. The elements affecting the Internet reception choice and selection, nonstop utilization of web- were distinguished among small and medium enterprise from the viewpoint of the Malaysian Tourism chiefs. The general results uncovered that the Technology Acceptance Model (TAM) gives a decent comprehension of these variables. A few elements from the audit were added to the primary TAM model. As per consequences of this examination, perceived attitude of Internet adoption plays the most important role in modifying the Internet adoption decision. Also, the findings show that perceived usefulness and perceived ease of use are the main reasons of a positive attitude of managers towards Internet adoption. The important antecedents of perceived usefulness are the perceived ease of use, facilitating conditions (financial and technological resources) and subjective norm, respectively. Likewise, perceived risk had negative effect on the perceived usefulness towards internet adoption. Furthermore, facilitating conditions and image are other factors with important effect on behavioral intention towards Internet adoption.

The outcomes demonstrate that facilitating conditions and perceived image are important antecedents of actual usage behavior. Attitude on Internet adoption decision as well as the findings revealed that decision makers receive some pressure from social factors to adopt Internet in order to make their enterprises more prestigious. Also, the other important factors in actual usage are perceived usefulness and behavioral intention. Eventually, regarding the exploration inquiry, factors influencing Internet adoption among the Malaysian Tourism Industries were identified by the theory of acceptance model. These are the subjective norm, perceived risk, facilitating conditions, image, attitude, perceived usefulness and perceived ease of use. Finally, these components were added to the TAM as an improved TAM model for Internet adoption among the Malaysian small and medium enterprises. 


\section{REFERENCES}

[1] H. P. Suriyapperuma, M. S. A. Yajid and A. Kkhatibi, "The Impact of Business Networking and Internet Adoption on SME performance in Sri Lanka", European Journal of Business and Management, 2015, Vol. 7, No. 17, pp. 236-245.

[2] M. I. Dahnil, K. M. Marzuki, J. Langgat and N. F. Fabeil, "Factors Influencing SMEs Adoption of Social Media Marketing", Procedia-Social and Behavioral Sciences, Vol. 148, 2014, pp. 119-126.

[3] T. Ramayah, S. L. Niu, S. K. Taghizadeh and S. A. Rahman, "Factors influencing SMEs website continuance intention in Malaysia", Telematics and Informatics, Vol. 33, No. 1, 2016, pp. 150-164.

[4] S. Kurnia, J. Choudrie, R. M. Mahbubur and B. Ahzougool, "E-commerce technology adoption: A Malaysian grocery SME retail sector study", Journal of Business Research, Vol. 68, No. 9, 2015, pp. 1906-1918.

[5] J. W. Peltier, Y. Zhao and J. A. Schibrowsky, "Technology adoption by small businesses: An exploratory study of the interrelationships of owner and environmental factors", International Small Business Journal, Vol. 30, No. 4, 2012, pp. 406-431.

[6] S. E. Grandón, S. A. Nasco and P. P. Mykytyn Jr., "Comparing theories to explain e-commerce adoption", Journal of Business Research, Vol. 64, No. 3, 2011, pp. 292-298.

[7] K. S. Tan, "Internet-based ICT adoption among SMEs: Demographic versus benefits, barriers, and adoption intention", Journal of enterprise information management, Vol. 23, No. 1, 2010. pp. 27-55.

[8] J. L. Gibbs and K. L. Kraemer, "A cross-country investigation of the determinants of scope of e-commerce use: an institutional approach", Electronic Markets, Vol. 14, No. 2, 2004, pp. 124-137.

[9] Financing SMEs and Entrepreneurs 2015: An OECD Scoreboard, Organisation for Economic Co-operation and Development, http://ifuturo.org/documentacion/Financing\%20SMES\%202015.pdf, 2015.

[10] ICT Facts and Figures 2015 - ITU, ICT Data and Statistics Division, https://www.itu.int/en/ITUD/Statistics/Documents/facts/ICTFactsFigures2015.pdf, 2015.

[11] H. Ongori and S. O. Migiro, "Information and communication technologies adoption in SMEs: literature review", Journal of Chinese Entrepreneurship, Vol. 2, No. 1, 2010, pp. 93-104.

[12] S. M. Mutula and P. van Brakel, "E-readiness of SMEs in the ICT sector in Botswana with respect to information access", The electronic library, Vol. 24, No. 3, 2006, pp. 402-417.

[13] S. Wolf and S. Chowdhury, "Use of ICTs and the economic performance of SMEs in East Africa", WIDER Discussion Papers//World Institute for Development Economics (UNU-WIDER), 2003.

[14] C. Hill, "International business: Competing in the global market place", Strategic Direction, Vol. 24, No. 9 , 2008.

[15] D. Pickernell, P. Jones, G. Packham, B. Thomas, G. White and R. Willis, "E-commerce trading activity and the SME sector: an FSB perspective", Journal of Small Business and Enterprise Development, Vol. 20, No. 4, 2013, pp. 866-888.

[16] L. Piris, G. Fitzgerald and A. Serrano, "Strategic motivators and expected benefits from e-commerce in traditional organisations", International Journal of Information Management, Vol. 24, No. 6, 2004, pp. 489506.

[17] S. Poon and C. Jevons, "Internet-enabled international marketing: A small business network perspective", Journal of Marketing Management, Vol. 13, No. 1-3, 1997, pp. 29-41.

[18] J. Torrent-Sellens, P. Ficapal-Cusi, J. Boada-Grauet and A. Vigil-Colet, "Information and communication 
technology, co-innovation, and perceived productivity in tourism small and medium enterprises: an exploratory analysis", Current Issues in Tourism, Vol. 19, No. 13, 2016, pp. 1295-1308.

[19] A. Pierce, "Small and Medium-Sized Enterprises in Tourism Industries", SME Financing Data Initiative, 2011.

[20] D. Buhalis and R. Law, "Progress in information technology and tourism management: 20 years on and 10 years after the Internet-The state of eTourism research", Tourism Management, Vol. 29, No. 4, 2008, pp. 609623.

[21] K. Set, "Exploring thE intErnEt Adoption on tourism smAll And mEdium EntErprisEs (tsmEs) in mAlAysiA", The Journal of Technology Management and Technopreneurship (JTMT), Vol. 2, No. 1, 2014, pp.71-84.

[22] K. Bong, "Sarawak eyeing six million tourists during VMY 2014.", tourismservicesmalaysia, 2013.

[23] Malaysia receives a record 25 million tourist arrivals last year, https://www.tourism.gov.my/media/view/malaysia-receives-a-record-25-million-tourist-arrivals-last-year, 2013.

[24] M. K. Hashim, S. Ahmad and M. Zakaria, "Internationalisation incentives and problems: insight from Malaysian SMEs", World Review of Entrepreneurship, Management and Sustainable Development, Vol. 6, No. 1, 2010, pp. 100-112.

[25] K. Sin Tan, S. C. Chong, B. Lin and U. C. Eze, "Internet-based ICT adoption: evidence from Malaysian SMEs", Industrial Management \& Data Systems, Vol. 109, No. 2, 2009, pp. 224-244.

[26] K. L. Chin and E. Chang, "A sustainable ICT education ontology", in Digital Ecosystems and Technologies Conference (DEST), 2011 Proceedings of the 5th IEEE International Conference on, 2011.

[27] M. K. Hashim, Business practices in Malaysia small and medium-sized enterprises, Universiti Utara Malaysia Press, 2006.

[28] S. S. Alam and M. K. Mohammad Noor, "ICT adoption in small and medium enterprises: An empirical evidence of service sectors in Malaysia", International Journal of Business and Management, Vol. 4, No. 2, 2009, pp. 112.

[29] K. S. Tan, U. C. Eze and S. C. Chong, "Effects of industry type on ICT adoption among Malaysian SMEs", Journal of Supply Chain and Customer Relationship Management, 2012, pp. 1-12.

[30] R. Law, A. Law and E. Wai, "The impact of the internet on travel agencies in Hong Kong", Journal of Travel \& Tourism Marketing, Vol. 11, No. 3, 2001, pp. 105-126.

[31] R. M. Y. Suraya, "Internet Diffusion and E-Business Opportunities Amongst Malaysian Travel Agencies", in Hawaii International Conference on Business, 2003.

[32] V. Vrana and C. Zafiropoulos, "Tourism agents' attitudes on internet adoption: an analysis from Greece", International Journal of Contemporary Hospitality Management, Vol. 18, No. 7, 2006, pp. 601-608.

[33] M. Intan Salwani, G. Marthandan, M. D. Norzaidi and S. C. Chong, "E-commerce usage and business performance in the Malaysian tourism sector: empirical analysis", Information Management \& Computer Security, Vol. 17, No. 2, 2009, pp. 166-185.

[34] N. H. Hashim, J. Murphy, S. Purchase and P. O'Connor, "Website and email adoption by Malaysian hotels", International Journal of Hospitality Management, Vol. 29, No. 1, 2010, pp. 194-196.

[35] B. AL-allak, "Evaluating the Adoption and Use of Internet-based Marketing Information Systems to Improve Marketing Intelligence (The Case of Tourism SMEs in Jordan)", International Journal of Marketing Studies, Vol. 2, No. 2, 2010. 
[36] T. Garín Muñoz and T. Perez-Amaral, "Internet usage for travel and tourism. The case of Spain", in $21^{s t}$ European Regional ITS Conference Copenhagen, 2010.

[37] Y.-C. Hung, Y-L. Yang, H-E. Yang and Y-H. Chuange, "Factors Affecting the Adoption of E-commerce for the Tourism Industry in Taiwan", Asia Pacific Journal of Tourism Research, Vol. 16, No. 1, 2011, pp. 105-119.

[38] B. Aldebert, R. J. Dang and C. Longhi, "Innovation in the tourism industry: The case of Tourism@", Tourism management, Vol. 32, No. 5, 2011, pp. 1204-1213.

[39] H. El-Gohary, "Factors affecting E-Marketing adoption and implementation in tourism firms: An empirical investigation of Egyptian small tourism organisations", Tourism management, Vol. 33, No. 5, 2012, pp. 12561269.

[40] R. Hussein, C. Ennew and W. Kortam, "The Adoption of Web-Based Marketing in the Travel and Tourism Industry: An Empirical Investigation in Egypt", Journal of Innovation Management in Small \& Medium Enterprises, 2012, pp. 1-23.

[41] S. Dahms and A. R. Dubey, "Internet adoption in travel agents across the United Arab Emirates (UAE). Evidence from four Emirates", Anatolia, Vol. 26, No. 1, 2015, pp. 85-88.

[42] M. Abou-Shouk and M. I. Eraqi, "Perceived barriers to e-commerce adoption in SMEs in developing countries: the case of travel agents in Egypt", International Journal of Services and Operations Management, Vol. 21, No. 3, 2015, pp. 332-353.

[43] I. Ajzen, "The theory of planned behavior", Organizational behavior and human decision processes, Vol. 50, No. 2, 1991, pp. 179-211.

[44] F. D. Davis, R. P. Bagozzi and P. R. Warshaw, "User acceptance of computer technology: a comparison of two theoretical models", Management science, Vol. 35, No. 8, 1989, pp. 982-1003.

[45] G. W. Downs Jr and L. B. Mohr, "Conceptual issues in the study of innovation", Administrative Science Quarterly, Vol. 21, No. 4, 1976, pp. 700-714.

[46] G. W. Downs and L. Mohr, "Toward a theory of innovation", Administration \& Society, Vol. 10, No. 4, 1979, pp. 379-408.

[47] S. Taylor and P. A. Todd, "Understanding information technology usage: A test of competing models", Information systems research, Vol. 6, No. 2, 1995, p p. 144-176.

[48] G. C. Moore and I. Benbasat, "Development of an instrument to measure the perceptions of adopting an information technology innovation", Information systems research, Vol. 2, No. 3, 1991, pp. 192-222.

[49] R. L. Thompson, C. A. Higgins and J. M. Howell, "Personal computing: toward a conceptual model of utilization", MIS quarterly, Vol. 15, No. 1, 1991, pp. 125-143.

[50] M. S. Eastin, "Diffusion of e-commerce: an analysis of the adoption of four e-commerce activities", Telematics and Informatics, Vol. 19, No. 3, 2002, pp. 251-267.

[51] L. J. Cronbach, "Coefficient alpha and the internal structure of tests",Ppsychometrika, Vol. 16, No. 3, 1951, pp. $297-334$

[52] SMECORP, "List of company", 2014 .

[53] T. A. Brown, Confirmatory factor analysis for applied research, Guilford Publications, 2015 
[54] D. T. Campbell and D. W. Fiske, "Convergent and discriminant validation by the multitrait-multimethod matrix", Psychological bulletin, Vol. 56, No. 2, 1959, pp. 81-105.

[55] C. M. Ringle, et al., "SmartPLS 2.0 (beta)", 2005.

[56] J. Henseler, C. M. Ringle and R. R. Sincovics, "The use of partial least squares path modeling in international marketing", Advances in International Marketing (AIM), Vol. 20, 2009. pp. 277-320.

[57] O. Götz, K. Liehr-Gobbers and M. Krafft, "Evaluation of structural equation models using the partial least squares (PLS) approach", Handbook of partial least squares, Springer, 2010, pp. 691-711.

[58] J. F. Hair, C. M. Ringle and M. Sarsted, "PLS-SEM: Indeed a silver bullet", Journal of Marketing Theory and Practice, Vol. 19, No. 2, 2011, pp. 139-152.

[59] M. Asyraf, "A Comparison Of Partial Least Square Structural Equation Modeling (PLS-SEM) and Covariance Based Structural Equation Modeling (CB-SEM) for Confirmatory Factor Analysis, International Journal of Engineering Science and Innovative Technology (IJESIT), Vol. 2, No. 5, 2013, pp. 198-205.

[60] T. Raykov, "Estimation of composite reliability for congeneric measures", Applied Psychological Measurement, Vol. 21, No. 2, 1997, pp. 173-184.

[61] J. F. Hair, W. C. Black, B. J. Babin and R. E. Anderson, Multivariate data analysis, New Jersey: Prentice Hall, 2006.

[62] C. Fornell and D. F. Larcker, "Evaluating structural equation models with unobservable variables and measurement error", Journal of Marketing Research, Vol. 18, No. 1, 1981, pp. 39-50.

[63] J. Henseler, C. M. Ringle and P. N. Ghauri, "The use of partial least squares path modeling in international marketing", Advances in international marketing, Vol. 20, No. 1, 2009, pp. 277-319. 